UDC 338.58.2

DOI: https://doi.org/10.32782/2224-6282/165-14

\author{
Naumenko Mariya \\ National Academy of the National Guard of Ukraine \\ ORCID: https://orcid.org/0000-0002-1974-2341
}

Науменко М. О. доктор філософії економічного напряму, професор, Національна академія Національної гвардії України

\title{
QUALITY CONTROL OF PURCHASED GOODS, WORKS AND SERVICES FOR THE NATIONAL GUARD OF UKRAINE
}

The purpose of the article is to create methodological bases for increasing the competitive position of organizations for tender procurement to meet the needs of units of the National Guard of Ukraine. Research methods are the use of optimization economic and mathematical models and computer simulation. In the article, by involving representatives of the command of the National Guard of Ukraine, an expert assessment of the impact of various factors in the specific conditions of the procurement process for the needs of logistics of military units. The degree of importance of each of the factors became the basis for the creation of a methodology for interaction of the partner organization with the relevant military unit. In turn, the proposed technique became the theoretical basis for the development of Microsoft Visual Studio 2010 decision support system. This information system helps to support management decisions to improve the effectiveness of the organization's interaction with the military unit of the NMU. The created prototype of the decision support system should be used to solve in the mode of dialogue poorly structured tasks of interaction of the organization with the military unit, which are characterized by incomplete input data, lack of existing standard procedures, incomplete clarity of goals and limitations. In global conditions, improving the competitiveness of the organization in terms of tender procurement will save the defence budget, will be an effective means of preventing corruption in the field of defence procurement, will create favourable conditions for the development of a competitive environment in public procurement and fair competition. The theoretical result of the article is the method of ensuring the competitiveness of the organization in terms of tender procurement for the needs of military units of the National Guard of Ukraine. The practical result is to substantiate the ways to increase the efficiency of the organization on the basis of ensuring competitiveness in terms of tender procurement for the needs of military units of the National Guard of Ukraine.

Keywords: tender purchases, military units, ensuring competitiveness.

JEL classification: D22, D61, D81

\section{КОНТРОЛЬ ЯКОСТІ ЗАКУПІВЕЛЬНИХ ТОВАРІВ, РОБІТ ТА ПОСЛУГ ДЛЯ НАЦІОНАЛЬНОЇ ГВАРДІЇ УКРАЇНИ}

\begin{abstract}
Метою статті є створення методичних засад підвищення конкурентних позицій організацій для проведення тендерних закупівель стосовно задоволення потреб підрозділів Національної гвардії України. Методами дослідження $є$ використання оптимізаційних економіко-математичних моделей та комп 'ютерне імітаційне моделювання. У статті иляхом залучення представників командування Начіональної гвардії України здійснено експертне оцінювання впливу різноманітних факторів в конкретних умовах реалізації процесу закупівель для потреб логістики військових підрозділів. Ступень важливості кожного з факторів стала підставою для створення методики взаємодії організації-партнера з відповідним військовим підрозділом. В свою чергу, запропонована методика стала теоретичною основою для розробки за допомогою Microsoft Visual Studio 2010 системи підтримки прийняття рішень. Ця інформаційна система сприяє підтримиі прийняття управлінських рімень стосовно підвищення рівня ефективності взаємодії організації з військовим підрозділом НГУ. Створений прототип системи підтримки прийняття рішень має використовуватися для вирішення в режимі діалогу погано структурованих завдань взаємодії організації з військовим підрозділом, для яких характерна неповнота вхідних даних, недостатність наявних стандартних процедур, неповна ясність иілей $і$ обмежень. В глобальних умовах вдосконалення прочесів забезпечення конкурентоздатності організації в умовах здійснення тендерних закупівель дасть змогу зекономити кошти оборонного бюджету, стане ефективним засобом запобігання проявам корупиії у сфері закупівель оборонного відомства, створить сприятливі умови для розвитку конкурентного середовища у сфері публічних закупівель та розвитку добросовісної конкурениії. Теоретичним результатом статті $\epsilon$ методика забезпечення конкурентоздатності організації в умовах здійснення тендерних закупівель для потреб військових підрозділів Національної гвардї України. Практичний результат полягає в обтрунтуванні шляхів підвищення ефективності організації на основі забезпечення конкурентоздатності в умовах здійснення тендерних закупівель для потреб військових підрозділів Національної гвардії Украӥни.
\end{abstract}

Ключові слова: тендерні закупівлі, військові підрозділи, забезпечення конкурентоздатності.

Formulation of the problem. The experience of countries with developed economies shows that in modern conditions the company succeeds if it focuses on the customer, provides high quality products and services, uses new management methods. Working with the customer at the company is a very important and integral part of the tender procurement process. This work is the starting and ending point of production.
Satisfaction of customer requirements is a key task of modern enterprises. The perfect method of interaction of the organization with the military units of the National Guard of Ukraine will ensure the achievement of competitiveness, which is one of the key factors for the success of the enterprise in the market.

Analysis of recent research and publications. The study of literature sources [1-7] showed that today the 
specialized literature addresses issues related to the formation of a stable competitive advantage in the market. But at the same time there is no comprehensive methodology governing the procedure for agreeing product parameters between the customer and the company, the basic principles of coordination, the lack of comprehensive accounting of the whole set of parameters and their detail.

Setting objectives. The purpose of the study is to improve the methodology of ensuring the competitiveness of the organization in terms of tender procurement for the needs of military units of the National Guard of Ukraine.

Presentation of the main research material. To improve the method of interaction of the organization with the military units of the National Guard of Ukraine (NGU) as potential customers for procurement, an expert assessment of the factors of counteraction to the competitive factors of the organization was conducted. Representatives of the command of military units of the NGU acted as experts.

Let's analyze the general picture of the importance of each of the factors of counteraction to the competitive factors of the organization according to the expert assessments of the representatives of the command of the military units of the NGU (Table 1).

Based on the importance of each of the factors of counteraction to competitive factors in the procurement process for the logistics needs of the NGU, we will describe an improved method of interaction between the organization and the military unit. It consists of the following stages:

1) analysis of market conditions and definition priorities of orders of NGU military units;

2) strategic positioning of products and services, provided;

3) clear definition and implementation of a unique set of benefits for military units of the NGU, which is provided by the enterprise and which cannot be provided by competitors;

4) ensuring economy, reliability and aesthetics of product design;
5) determination of expectations of NGU military units regarding product quality;

6) providing information support for the organization's interaction with the NGU military unit on the basis of appropriate automation systems;

7) use of modern automated production management systems;

8) provision of original services to NGU military units;

9) personification of NGU military units as customers of products.

The proposed method for managing the effectiveness of the organization's interaction with military units of the National Guard of Ukraine was implemented as a prototype of a decision support system (DSS). We substantiate the choice of DSS development to solve the task.

Decision Support System (DSS) is a special interactive information system that uses hardware, software, data, model base and manager's work to support poorly structured and unstructured decisions by direct users-managers in the process of analytical modeling based on the provided set of technologies [8]. DSS is the main category of management information systems that support managers in the process of making unstructured and semi-structured decisions. DSS uses analytical models, specialized databases, an interactive solution modeling process on a computer, as well as subjective opinions of the user. DSS - mobile unique systems that are managed and controlled by managers who use them to make specific decisions. The main components of DSS are: hardware, software, data, models and work of the manager.

The prototype is a simplified workable model of DSS, which is developed, as a rule, at the user's workplace, and as needed is gradually refined. Using a prototype helps to clarify the user's own requirements and understanding of the decision situation. Each new successful use of DSS can adapt the system to make a different kind of decision. The prototype can be gradually refined and supplemented on site. The efficiency

Analysis of expert assessment of the importance of factors to ensure the competitiveness

Table 1 of the organization in the procurement process for the logistics needs of the NGU

\begin{tabular}{|c|c|c|c|c|}
\hline \multirow{2}{*}{ A set of factors counteracting the competitive factors of the organization } & \multicolumn{3}{|c|}{ Experts } & \multirow{2}{*}{ GPA } \\
\hline & 1 & 2 & 3 & \\
\hline $\begin{array}{l}\text { Maintaining a clearly specialized product catalog and ensuring the unification of the } \\
\text { method of presenting information. }\end{array}$ & 4 & 3 & 3 & 3,3 \\
\hline Strategic positioning of products and services provided. & 4 & 4 & 5 & 4,7 \\
\hline Systematic renewal of the fleet of equipment for manufacturing products & 5 & 4 & 5 & 4,6 \\
\hline $\begin{array}{l}\text { Expansion of the infrastructure of the market organization due to the effect of scale } \\
\text { and strengthening the concentration of the branch and divisions for the convenience of } \\
\text { interaction with the customer. }\end{array}$ & 2 & 2 & 2 & 2 \\
\hline Use of modern automated production management systems. & 4 & 2 & 5 & 3,7 \\
\hline Inclusion of automated components in technological production chains. & 4 & 4 & 5 & 4,3 \\
\hline $\begin{array}{l}\text { Providing information support for interaction with the customer products based on the } \\
\text { appropriate automation system. }\end{array}$ & 3 & 3 & 4 & 3,3 \\
\hline Defining customer expectations regarding product quality. & 5 & 5 & 5 & 5 \\
\hline Ensuring the economy, reliability and aesthetics of product design. & 4 & 5 & 5 & 4,7 \\
\hline Personification of NGU military units as customers of products. & 4 & 4 & 4 & 4 \\
\hline Clear definition and implementation of a unique set of benefits for NGU military units. & 5 & 5 & 5 & 5 \\
\hline $\begin{array}{l}\text { Implementation of individualization of production in accordance with the needs of } \\
\text { military units of the NGU. }\end{array}$ & 4 & 4 & 4 & 4 \\
\hline Providing original services. & 5 & 5 & 5 & 5 \\
\hline Provision of new ancillary services to NGU military units. & 4 & 5 & 5 & 4,7 \\
\hline
\end{tabular}

Source: authors' own development 
and depth of elaboration of possible development alternatives are related to the ability to freely use modern DSS - the core of management information systems (ISM).

The development of a management solution in the general case is a very time-consuming procedure for identifying the problem, developing criteria and identifying alternatives and limitations, finding the best alternatives or, if possible, their optimal synthesis.

The art of the manager who develops the management decision consists in the correct choice of model of the solved problem and, as a consequence, a method of its decision. It should be noted that the practicing manager must be able to solve a direct problem, ie to classify the problem according to the proposed features and choose a solution based on the result of the classification.

Management is a purposeful influence on the controlled parameters of the system, in which it is always possible to distinguish between the part that is controlled (control object) and the part that controls (control subject).

With the help of universal computer tools created for DSS, professionals must be able to solve complex professional problems using mobile fundamental methods. The practical application of methods is accelerated by effective software tools.

At the entrance of the designed prototype DSS will be able to show the problem, and at the exit to get the target intellectual action (evaluation, choice, solution). When solving any laboratory problem, it is useful to seek to see a problem that does not always clearly appear in the condition of the problem, to understand the possible target intellectual action.

Using a spreadsheet package, managers can analyze a wide range of issues, including the impact of different budget operations on the purpose of individual production operations. Based on the results of such analysis, managers can choose the alternative solution that best meets the requirements of a particular production site.

DSS as any information system designed to solve a certain area of problems, is created as a result of systems engineering (performing a systematic process - a set of discrete and interconnected phases, which solve a particular problem). These phases transform the needs of ATS with the support of their own reflections into a specific system configuration.
The impact of the DSS environment is the profile of the task, the rules and procedures of the visual area, the level of use of DSS, the decision-making phase that needs support.

DSS components reflect the functional division of the system into separate subsystems in terms of its design. The main components of DSS: database, software system, user interface.

At the stage of DSS development it is very important to choose the right software product in which it is developed. When analyzing the resources required for DSS engineering, the availability of information processing hardware and software should be considered [9].

Microsoft Visual Studio 2010 and the C \# programming language were chosen as the software product in which DSS is developed. It is a professional language needed to solve a wide range of tasks. The $\mathrm{C}$ \# programming language provides the ability to develop Windows applications that are very easy to use for the end user, ie the consumer of the developed product. In addition, the Microsoft Visual Studio 2010 environment provides the ability to connect to the developed product end products of other environments, such as Microsoft Access. This factor will provide an opportunity in the subsequent stages to create a full-fledged DSS.

The advantages of developing a prototype DSS effective interaction of the organization with the military units of the National Guard of Ukraine using the platform Microsoft Visual Studio 2010 include:

* .exe product format does not require additional software installation;

developed Windows-applications are attractive and easy to use for the user;

Microsoft Visual Studio 2010 provides the ability to integrate with products from other platforms and applications.

The user interface will be used for efficient work of the organization manager with the DSS prototype. The main menu allows you to choose from three tasks, which helps to solve the developed prototype DSS (Figure 1).

If the user selects the menu item "Positioning of the organization" he will be displayed a form (Figure 2), in which you must enter statistics of the organization for the last year. tistics:

The user must have information on the following sta-

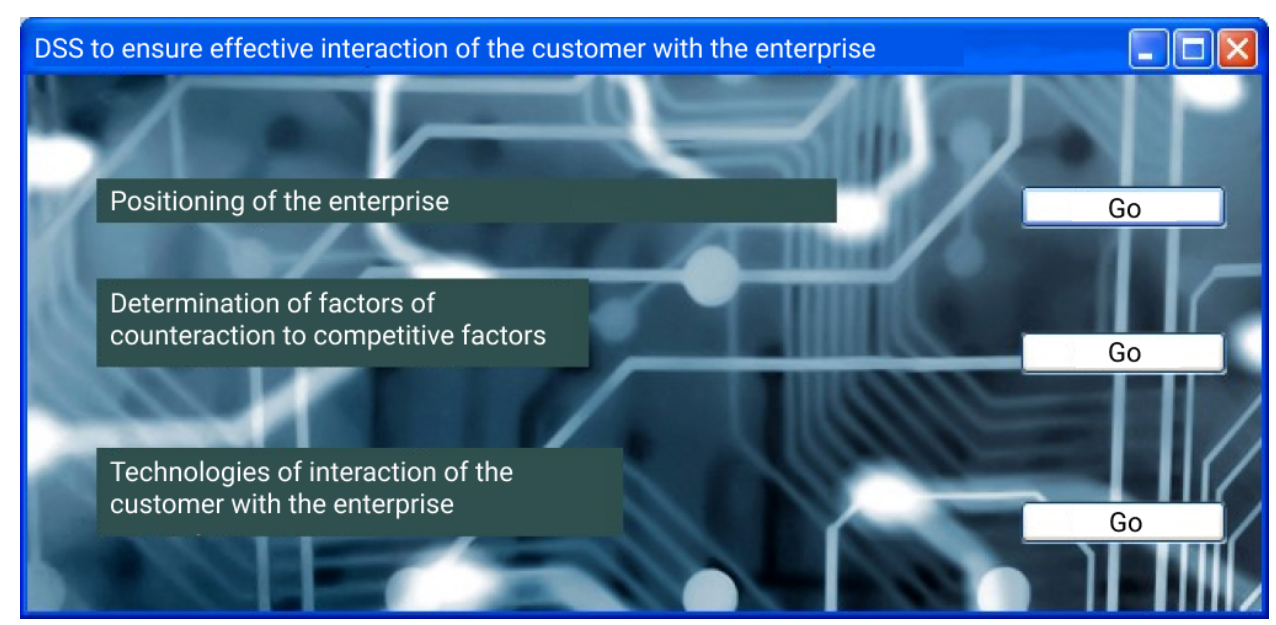

Figure 1. Menu of the prototype of the decision support system to ensure effective interaction of the organization with the military unit of the NGU Source: authors' own development 


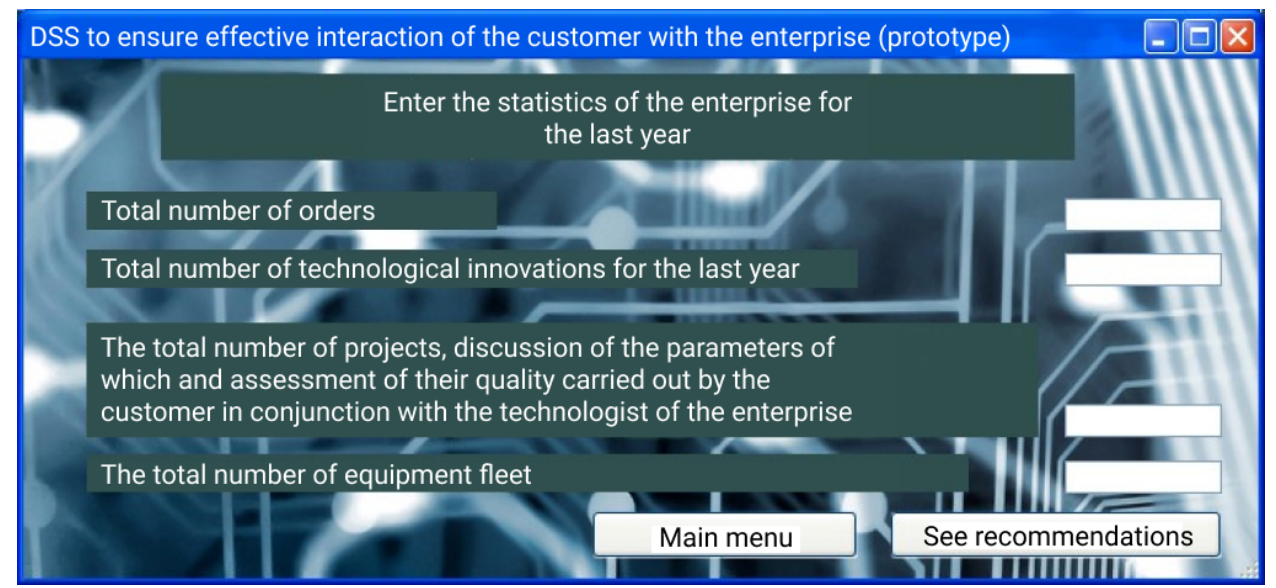

Figure 2. Form of entering statistical data for effective positioning of the organization Source: authors' own development

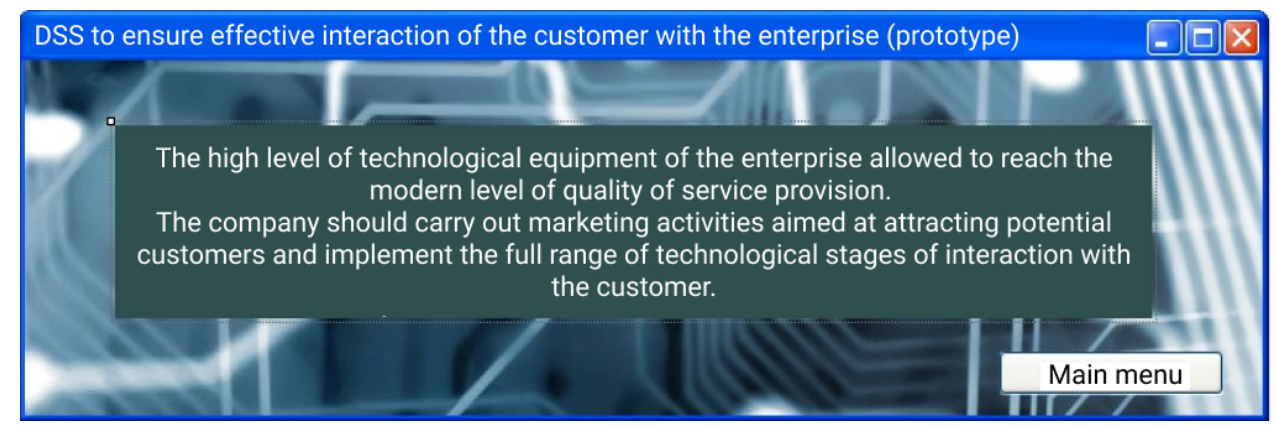

Figure 3. Recommendations for the effective positioning of the organization in the market for tender procurement, formed by the prototype DSS

Source: authors' own development

1) the total number of orders;

2) the number of technological innovations for the last year;

3) the number of projects, the discussion of the parameters of which and the assessment of their quality conducted by the customer in conjunction with the technologist of the organization;

4) the total number of modern equipment.

After entering data and clicking on the "View recommendations" button, the system automatically calculates

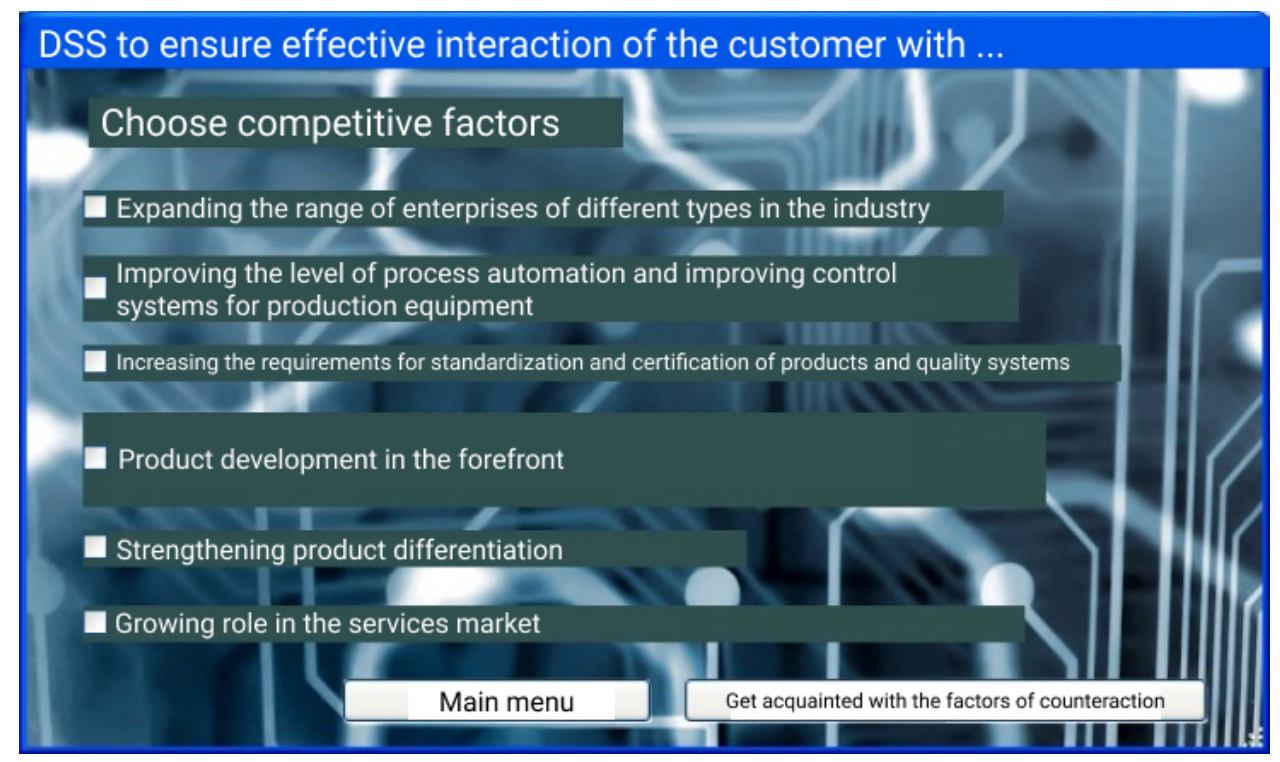

Figure 4. The form of choice of competitive factors of the organization Source: authors' own development 
the intensity of the organization's interaction with the customer and the level of technological equipment of the organization and generates recommendations for further effective positioning of the organization in the market for tender procurement (Figure 3).

The second task, which solves the developed prototype of the decision support system, is the formation of factors to counteract the possible competitive factors faced by the enterprise (Figure 4).

Immediately after the user selects a competitive factor, a list of countermeasures to the selected competitive factor will be automatically issued.

Thus, the prototype of the decision support system is used to solve in the mode of dialogue poorly structured tasks, which are characterized by incomplete input data, lack of existing standard procedures, incomplete clarity of objectives and limitations. Manager, if necessary, can interfere with the decision, modify the input data, processing procedures, objectives and task constraints. The choice of strategies for evaluating alternative solutions is an exclusive function of the user.

Conclusions. In this scientific work the technique of maintenance of competitiveness of the organization in the conditions of realization of tender purchases for needs of military divisions of National guard of Ukraine is offered.

The scientific result of this work was the methodological support of the competitiveness of the organization in terms of tender procurement for the needs of military units of the National Guard of Ukraine.

The practical result of scientific work is the recommendations to the management of the organization to ensure competitiveness in terms of tender procurement for the needs of military units of the National Guard of Ukraine.

\section{References:}

1. Hrabovskyi Y., Yevsyeyev. O. (2018) Development of methodological principles of supportpreservation engineering work. Technology audit and production reserves, no. 2(2), pp. 43-49. DOI: https://doi.org/10.15587/2312-8372.2018.127776

2. Naumenko M.O., Ryha O.S. (2018) Pidkhody do zabezpechennia stratehichnoho upravlinnia pidpryiemstv v umovakh nestiikoho seredovyshcha [Approaches to ensuring strategic management of enterprises in an unstable environment]. Bulletin of Transport Economics and Industry (collection of scientific and practical articles), no. 63, pp. 216-223. (in Ukrainian)

3. Sokolovskyi S.A., Naumenko M.O. (2018) Analiz osoblyvostei upravlinnia informatsiinymy potokamy lohistychnykh protsesiv pidrozdiliv Natsionalnoi hvardii Ukrainy [Analysis of the peculiarities of information flow management of logistics processes of the National Guard of Ukraine]. Scientific Journal «ScienceRise», no. 2, pp. 19-21. (in Ukrainian)

4. Wan X., Dresner M. (2015) Losing the Loop: An Empirical Analysis of the Dynamic Decisions Affecting Product Variety. Decision Sciences Journal, no. 46(6), pp. 1141-1164.

5. Naumenko M., Hrabovskyi Y. (2018) Elaboration of methodology for designing a publishing and printing web portal. Eastern-European Journal of Enterprise Technologies, no. 2(92), pp. 14-22. DOI: https://doi.org/10.15587/1729-4061.2018.126305

6. Gilmore, D. A. (2010) Decade of Supply Chain Management. Supply Chain Digest, 15.

7. Mezhdybovska N.S. (2011) Elektronne postachannia: pravyla dosiahnennia uspikhu [E-delivery: rules for success]. Biuleten Mizhnarodnoho Nobelevskoho ekonomichnoho forumu, no. 1(4), pp. 261-265. (in Ukrainian)

8. Hrabovskyi Ye.M. (2019) Analiz vykorystannia multymediinykh komponentiv v suchasnykh tekhnolohiiakh mobilnoho navchannia [Analysis of the use of multimedia components in modern mobile learning technologies]. Scientific Journal «ScienceRise», no. 4(57), pp. 46-50. (in Ukrainian)

9. Hrabovskyi Y., Fedorchenko V. (2019) Development of the optimization model of the interface of multimedia edition. EUREKA: Physics and Engineering, no. 3, pp. 3-12. DOI: 10.21303/2461-4262.2019.00902

\section{Список використаних джерел:}

1. Hrabovskyi Y., Yevsyeyev. O. Development of methodological principles of supportpreservation engineering work. Technology audit and production reserves. 2018. № 2(2). P. 43-49. DOI: https://doi.org/10.15587/2312-8372.2018.127776

2. Науменко М.О., Рига О.С. Підходи до забезпечення стратегічного управління підприємств в умовах нестійкого середовища. Вісник економіки транспорту і промисловості (збірник науково-практичних статей) УдУЗТ. 2018. № 63. С. $216-223$.

3. Соколовський С.А., Науменко М.О. Аналіз особливостей управління інформаційними потоками логістичних процесів підрозділів Національної гвардії України. Scientific Journal «ScienceRise». 2018. № 2. C. 19-21.

4. Wan X., Dresner M. Losing the Loop: An Empirical Analysis of the Dynamic Decisions Affecting Product Variety. Decision Sciences Journal. 2015. № 46(6). P. 1141-1164.

5. Naumenko M., Hrabovskyi Y. Elaboration of methodology for designing a publishing and printing web portal. Eastern-European Journal of Enterprise Technologies, 2, 2(92), 14-22. DOI: https://doi.org/10.15587/1729-4061.2018.126305

6. Gilmore D.A. Decade of Supply Chain Management. Supply Chain Digest. 2010, 15.

7. Междибовська Н.С. Електронне постачання: правила досягнення успіху. Бюлетень Міжнародного Нобелевського економічного форуму. 2011. № 1(4). С. 261-265.

8. Грабовський Є.М. Аналіз використання мультимедійних компонентів в сучасних технологіях мобільного навчання. Scientific Journal «ScienceRise». № 4(57). 2019. C. 46-50.

9. Hrabovskyi Y., Fedorchenko V. Development of the optimization model of the interface of multimedia edition. EUREKA: Physics and Engineering. 2019. № 3. Pp. 3-12. DOI: 10.21303/2461-4262.2019.00902 